Congressional Fellowship Program Alumni Name Daniel Patrick Moynihan Outstanding Legislator, 103rd Congress

In December 1993 the Alumni Association of the Congressional Fellowship Program selected Senator Daniel Patrick Moynihan as the Outstanding Legislator of the 103rd Congress. The award was presented at a reception July 12, 1994, in the Capitol.

Previous recipients of the Outstanding Legislators awards are: Representative Morris Udall, 96th Congress; Senator Robert Dole, 99th Congress; Representative Thomas Foley, 100th Congress and Senator Richard Lugar, 102nd Congress.

\section{Congressional Fellowship Program Announces 1994-95 Competition Winners}

Political Scientists, Reporters Named APSA Congressional Fellows

The American Political Science Association has announced the winners in the national competition for the 1994-95 Congressional Felloship Program. Following a onemonth orientation seminar, Fellows work full time for nine months as professional staff assistants to members of Congress or congressional committees.

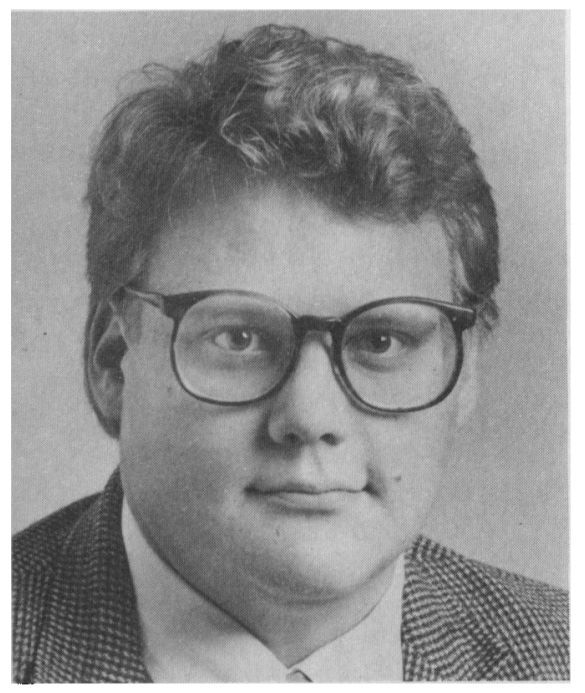

David Eskola

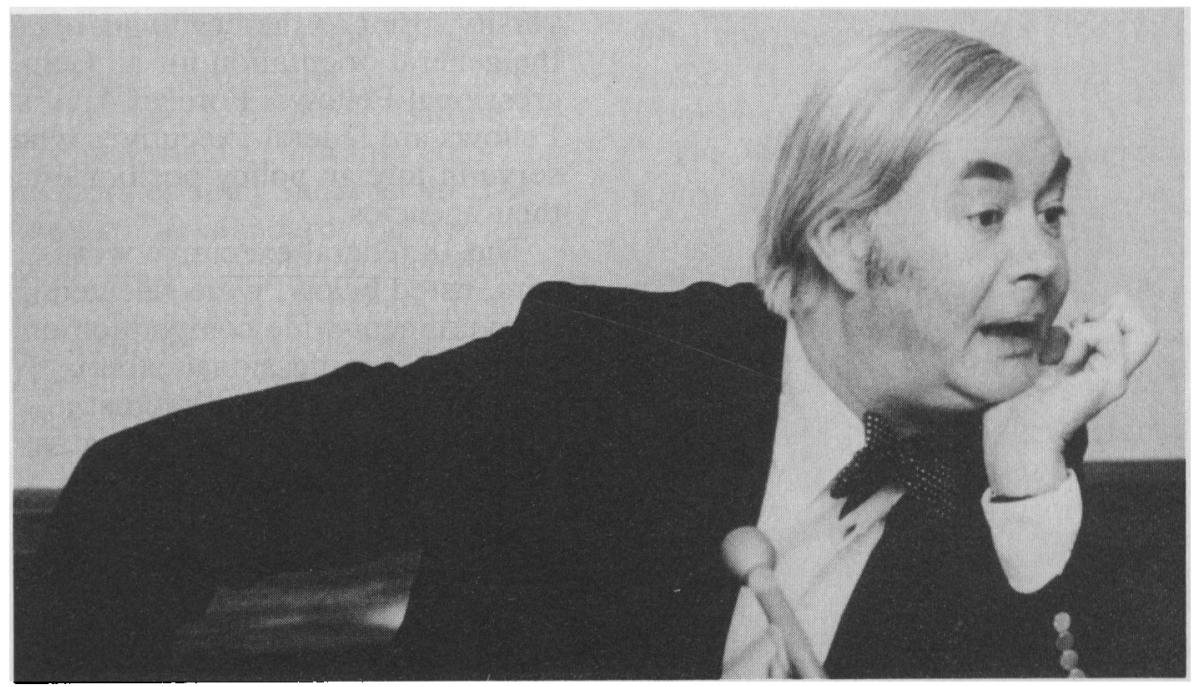

Daniel Patrick Moynihan

The New Political Science and Journalism Congressional Fellows are:

David Eskola, Television Columnist, The Greenville News, Greenville, $\mathrm{SC}$

Kenneth Finegold, Assistant Professor, Department of Political Science, Rutgers University

Douglas Johnson, Senior Producer/ Acting Managing Editor, Michigan Public Radio Network

Robin Kolodny, Assistant Professor, Department of Political Science, Temple University

Forrest Maltzman, Assistant Professor, Department of Political Science, The George Washington University

Stephen McDowell, Sessional Lecturer, Carleton University, Ottawa, Canada

Cheryl Miller, Associate Professor, Department of Political Science and Policy Sciences Graduate Program, University of Maryland, Baltimore County

Lori Nitschke, City Government and Local Politics Reporter, Grand Forks Herald, Grand Forks, ND

Timothy Prinz, Assistant Professor, Government and Foreign Affairs, University of Virginia

Karen Weintraub, Urban Affairs Beat Reporter, Houston Post, Houston, TX

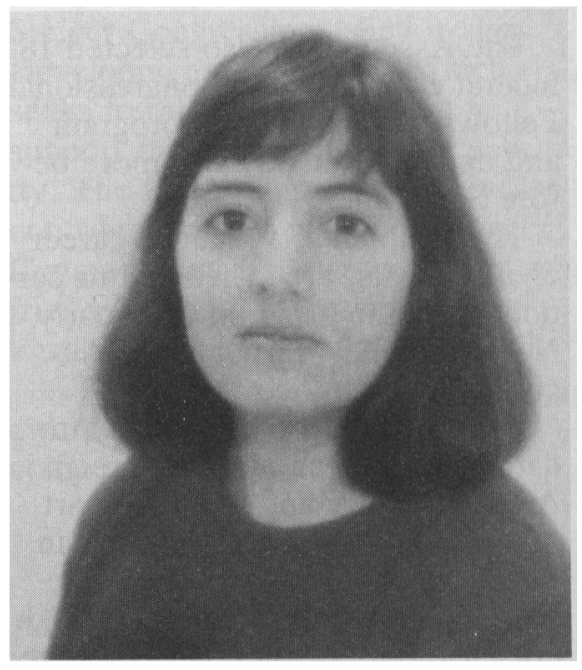

Robin Kolodny

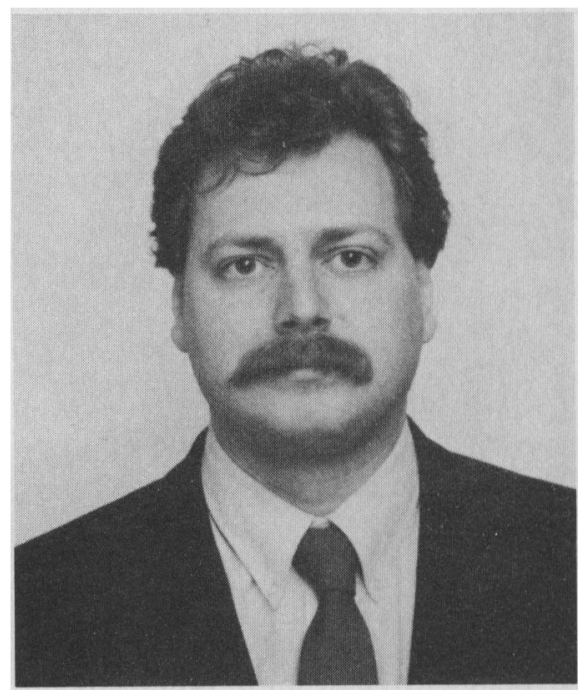

Stephen McDowell 


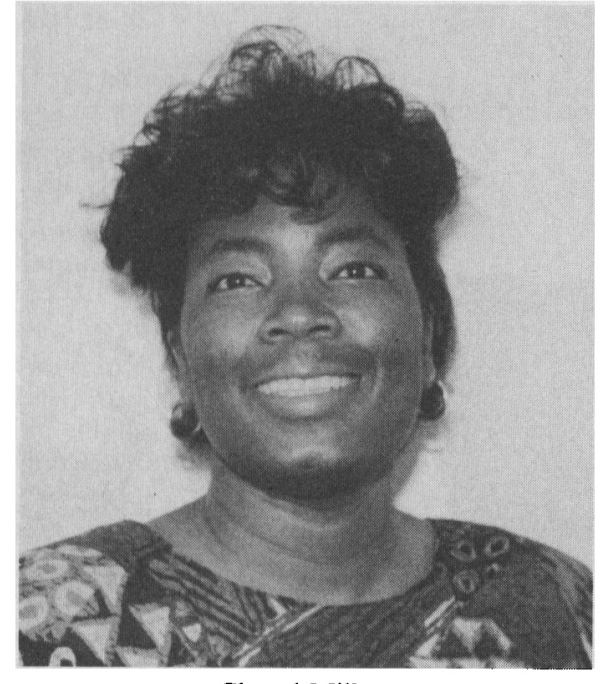

Cheryl Miller

Federal Executives Win Congressional Fellowships

The Association also selected 18 federal executives as Congressional Fellows for the 1994-95 program and expects to name two more before September.

The recipients, advanced career civil servants, are scheduled to participate in the program from early November 1994 through mid-August 1995.

Of the 18 federal executives, to date, 7 have been named Foreign Affairs Fellows and will take part in a special two-month seminar in Congress and foreign policy. The course is taught by Professor Frederick Holborn at the Paul H. Nitze School of Advanced International Studies, The Johns Hopkins Uni-

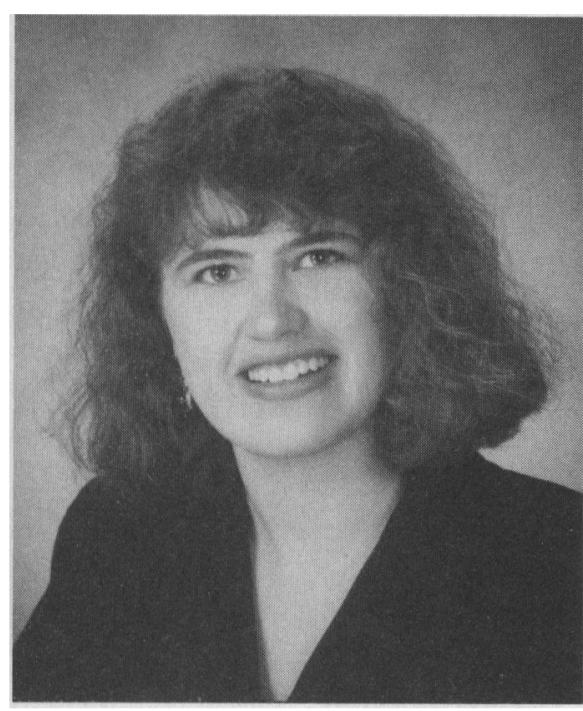

Lori Nitschke versity, prior to the beginning of the general orientation for all Congressional Fellows. Foreign Affairs Fellows are federal executives who serve in foreign policy positions in their agencies.

The 18 federal executive winners, listed below, were selected in a government-wide competition on the basis of professional experience, career goals and interest in national politics and the legislative process.

Barbara J. Barger, Civilian Personnel Officer, Department of the Air Force

Thomas E. Chesno, E62 Chief, National Security Agency

Howard R. Dobson, International Economist, Office of International Economic Affairs, Department of Labor

Roy R. Fairchild, Chief, Network Systems Division, Central Intelligence Agency

Kim A. Hildred, Disability Program Administrator, Social Security Administration

Milton E. Hill, Chief, Planning and Workforce Diversity, Bureau of Land Management, Department of the Interior

Joanne J. Quillette, Computer Aided Design Project Engineer, Department of the Navy

Patricia A. Palmer, Senior Operational Staff Officer, National Security Agency

Debra A. Purvis, Environmental Protection Specialist, Office of American Indian Trust, Department of the Interior

Cynthia M. Shirk, Health Insurance Specialist, Specialty Long Term Care Services Branch, Department of Health and Human Services

George A. Stickels, Agricultural Program Specialist, Agricultural Stabilization and Conservation Service, Department of Agriculture

\section{Foreign Affairs Fellows}

Timothy S. Dwight, Major, Aviation Staff Officer, Departments of the Army and Air Force, National Guard Bureau

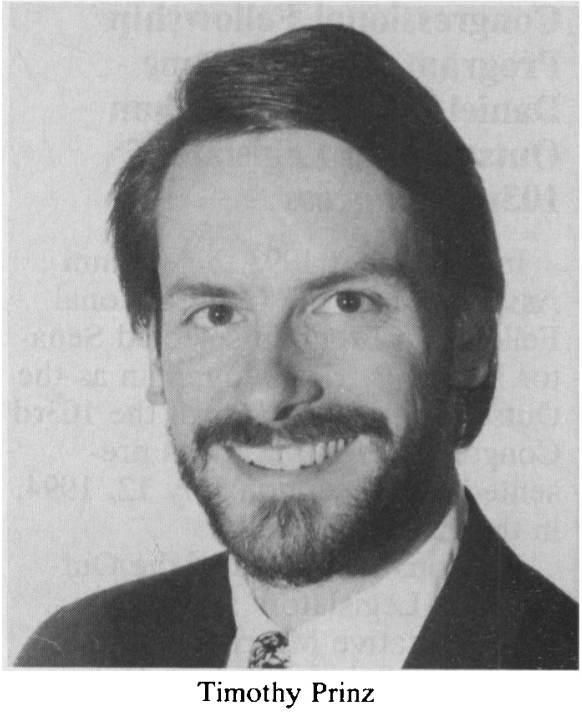

William W. McIlhenny, Action Officer for Latin American Issues, Office of U.N. Political Affairs, Department of State

Creda P.J. Parham, Director, Public and Employee Information, Central Intelligence Agency

Patricia A.H. Saulsbery, LTC, Assistant Chief, Army Nurse Corps, Department of the Army

Ellen M. Shimko, Analyst, Office of Slavic and Eurasian Analysis, Central Intelligence Agency

Peter C. Simoncini, LTC, Professor of Military Science, Department of Military Science, Department of the Army

Yvette C. Wooley, Senior Regional Analyst for South America, Defense Intelligence Agency

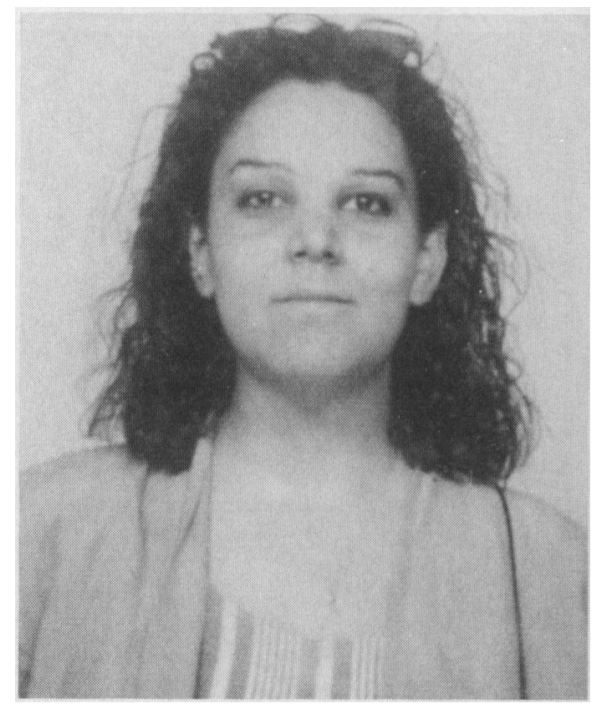

Karen Weintraub 
Political Scientists and Journalists Winners of Designated Congressional Fellowships

David Escola and Stephen McDowell Named APSA-MCI Communications Congressional Fellows

David Eskola, television columnist for the Greenville News, Greenville, SC; and Stephen McDowell, lecturer in the school of Journalism and Communication, Carleton University, Ottawa, have been named the 1994-95 APSAMCI Communications Congressional Fellows.

Mr. Eskola has been with the Greenville News since 1984. Before becoming a television columist in 1987 he was a government and police reporter. He graduated from Northwestern University's Medill School of Journalism with a Bachelor of Science degree in 1984.

Before joining Carleton University in 1991, Dr. McDowell conducted research on telecommunications in North America, Europe and Asia. He has published widely on communications policies in a number of countries and on international trade and investment in telecommunications services. Dr. McDowell received his Ph.D. in political science at York University in Toronto in 1988.

\section{Douglas Johnson: Joan \\ Shorenstein Barone Congressional Fellow}

Douglas Johnson, Senior Producer and Acting Managing Editor of the Michigan Public Radio Network, is the recipient of the 1994 95 Joan Shorenstein Barone

Congressional Fellowship. This Fellowship is awarded to an outstanding broadcast journalist through annual national competition.

Mr. Johnson has been with Michigan Public Radio since 1987 where he edits, produces and hosts State Edition, a live daily news and information magazine. He has worked in broadcast for NBC Radio and National Public Radio, and won a 1992 Governor's Award for Excellence in Arts Reporting. Mr. Johnson received his Bachelor's degree with honors in psychology from Michigan State University in 1989.

The Joan Shorenstein Barone Congressional Fellowship commemorates Joan Shorenstein Barone and the standards she set for accurate, thorough and dignified reporting of current events, first as a researcher at the Washington Post and subsequently as a producer for CBS News.

Funding for the Joan Shorenstein Barone Congressional Felloship is generously provided by her parents, Walter and Phyllis Shorenstein, and family.

\section{Lori Nitschke: Poynter Fellow}

Lori Nitschke, reporter for the "Grand Forks Herald" in Grand Forks, ND, has been named the 1994-95 Poynter Fellow. The Fellowship is awarded to an outstanding print journalist.

Ms. Nitschke has been with the "Grand Forks Herald" since 1992, covering city government and local politics. She graduated summa cum laude with a Bachelor's degree in journalism and political science from the University of North Dakota, where she was named the outstanding journalism graduate in her class.

Funding for the 1994-95 Poynter Fellow is generously provided by Congressional Quarterly Inc., publishers of a family of resources that inform the public about Congress, national issues and the American political process. Congressional Quarterly was founded in 1945 by Nelson Poynter.

\section{Timothy Scott Prinz: William A. Steiger Congressional Fellow}

Timothy Scott Prinz, Assistant Professor of Government and Foreign Affairs, University of Virginia, has been named the 1994-95 William A. Steiger Congressional Fellow.

Dr. Prinz has been on the faculty of the University of Virginia since 1991 and was nominated for Phi Eta Sigma Teacher of the Year in 1992. He graduated summa cum laude with his Bachelor's degree from the University of Dayton in
1983 and received his MA (1985) and Ph.D. in government (1991) from Harvard University.

The William A. Steiger Congressional Fellowship honors the memory of William A. Steiger, a Republican who represented the Sixth District of Wisconsin from 1966 until his untimely death in 1978 . During his service in Congress, he was dedicated to the Congressional Fellowship Program and was an active member of its advisory committee. The Fellowship is awarded annually to a political scientists or journalist who best exemplifies Representative Steiger's values and interests.

Fundraising for the William A. Steiger Congressional Fellowship is under the direction of the William A. Steiger Congressional Fellowship Development Committee, which seeks to raise an endowment to support the Fellowship in perpetuity. The Fellowship fund receives contributions annually from former Congressional Fellows and other friends of the Congressional Fellowship Program.

All designated fellowships are awarded through rigorous national competition.

\section{APSA Headquarters Building Handicapped Accessible}

The early spring saw substantial changes to the APSA Headquarters Building at 1527 New Hampshire Avenue, NW, Washington, DC. The last stage of a two year effort to make the building hospitable to the handicapped was completed with the addition of a ramp to the rear of the building to accommodate members and visitors in wheel chairs. The first two stages of the accessibility effort were to guarantee that the existing elevator met wheel chair requirements, and to remodel a lavatory on the building's third floor to make it handicapped accessible. Now all stages are complete and all APSA members will be able attend committee meetings and other activities held in the headquarters building. 